\title{
Adolescents with chronic headaches- mental health problems and coping patterns
}

\author{
S Hartberg ${ }^{1 *}$, C Lundqvist $^{2}$, J Clench-Aas ${ }^{3}$, RK Raanaas ${ }^{1}$ \\ From The European Headache and Migraine Trust International Congress \\ London, UK. 20-23 September 2012
}

\section{Introduction/purpose}

Most studies on chronic headache have focused on adults, but chronic headache is also a major problem in children and adolescents [1]. There are gaps in knowledge of coping and mental health problems in adolescents with chronic headaches [2]. The aim of the present study is to get a better understanding of the relationship between different coping strategies and the presence of chronic headache either alone or in combination with mental health problems.

\section{Methods}

This study is based on a self-report cross-sectional study undertaken in Akershus County in Norway in 2002. A total of 19,985 adolescents were included in this study, covering lower secondary and upper secondary students, aged 13-19 years. Mental health was assessed by using the Strengths and Difficulties Questionnaire (SDQ). Chronic headache was measured with a single item, defined in close accordance with the classification of the International Headache Society (ICHD-2). Internal and external coping strategies were assessed through seven items, based on the question: What do you do/what happens when you are burdened by painful thoughts and feelings?

\section{Results}

Adolescents with chronic headaches showed more symptoms of mental health problems overall compared to those without chronic headache or with mental health problems alone. Logistic regression analyses showed that those adolescents having both chronic headaches and comorbid mental health problems to a greater extent used internal coping strategies, such as keeping feelings inside (OR 2.05), using drugs (OR 1.79) and talking

${ }^{1}$ Norwegian University of Life Sciences, Norway

Full list of author information is available at the end of the article oneself out of problems (OR 1.55), compared to those with chronic headache alone.

\section{Conclusion}

We suggest that attention should be paid towards coping strategies used by a high risk group that have both chronic headaches and mental health problems.

\section{Author details}

'Norwegian University of Life Sciences, Norway. ${ }^{2} \mathrm{H} \varnothing \mathrm{KH}$, Research Centre, Akershus University Hospital, Norway. ${ }^{3}$ Norwegian Institute of Public Health, Norway.

Published: 21 February 2013

\section{References}

1. Gladstein J: Children and adolescents with chronic daily headache. Curr Pain Headache Rep 2004, 8:71-75.

2. Compas BE, Connor-Smith JK, Saltzman H, Thomsen AH, Wadsworth ME: Coping with stress during childhood and adolescence: problems, progress, and potential in theory and research. Psychol Bull 2001, 127:87-127.

doi:10.1186/1129-2377-14-S1-P8

Cite this article as: Hartberg et al:: Adolescents with chronic headachesmental health problems and coping patterns. The Journal of Headache and Pain 2013 14(Suppl 1):P8

Submit your manuscript to a SpringerOpen ${ }^{\circ}$ journal and benefit from:

- Convenient online submission

- Rigorous peer review

- Immediate publication on acceptance

- Open access: articles freely available online

- High visibility within the field

- Retaining the copyright to your article

Submit your next manuscript at $>$ springeropen.com
(C) 2013 Hartberg et al; licensee Springer. This is an Open Access article distributed under the terms of the Creative Commons Attribution License (http://creativecommons.org/licenses/by/2.0), which permits unrestricted use, distribution, and reproduction in any medium, provided the original work is properly cited. 